\title{
Developing Instructional Media of Android-Based Game to Teach Human Senses
}

\author{
Putri Khoirin Nashiroh ${ }^{1}$, Ahmad Fashiha Hastawan ${ }^{2}$, Tangguh Al Fatah ${ }^{3}$, and Aditya Permana ${ }^{4}$ \\ Departemen of Electrical Engineering, Universitas Negeri Semarang, Semarang, Indonesia ${ }^{1234}$ \\ putrikhoirin@mail.unnes.ac.id ${ }^{l}$,ahmad.fashiha@mail.unnes.ac.id ${ }^{2}$, \\ tangguhalfatah@students.unnes.ac.id ${ }^{3}$ aditya_permana@students.unnes.ac.id ${ }^{4}$
}

Keywords: Instructional Media, Android, Game, Human Senses

\begin{abstract}
The use of conventional teaching methods in learning activity can decrease student motivation to learn because students receive learning passively, this situation can cause students to feel bored. Thus, the need for innovation in the learning process in order to form the learning process interesting and fun is needed, that it can stimulate thoughts, feelings and desires of students. That condition can encourage the creation of learning in students, too. Innovations that can be implemented are by utilizing Android games as a Instructional Media, which is now widely used in various fields, including in education. The utilization can be applied in science subjects to teach human senses. This application was developed using the Multimedia Development Life Cycle (MDLC) and testing methods using Blackbox Testing. The Results from the trial showed that the application can function properly, so this instructional media is ready to be implemented in learning activities.
\end{abstract}

\section{INTRODUCTION}

In the classroom, teachers are still using conventional methods. The conventional method is a method of using the lecture in communication between teachers and students (Kuswanto and Walusfa, 2017), The method can reduce the motivation of students to learn because just pay attention and listen to the teacher, so students will feel tired(Goddess, Isnanto and Martono, 2017),

On the subjects of Science and Natural Sciences of 4th grade elementary schools, there is material about the Five Senses. This material would require images as a media in learning activity, so, students can understand the parts and the functions of the five senses better. In many activities of learning, teachers still using Student Worksheet. This condition causes students to read too much text without clear visualization of the five senses. The pictures presented in Student Worksheet was not so clear because it was printed using frosted paper and the color of the text is black, not printed in color as they should. Whereas in learning, the message delivered by the teacher must be received clearly by the students to form a learning process.(Goddess, Isnanto and Martono, 2017).
Thus, the need for innovation in the learning process is needed to form the learning process, so the learning activity becomes interesting and fun. The innovation can use existing technology. Multimedia is one of today's technology that can be used for instructional media. Multimedia as an instructional media can be applied so that the communication process in student learning will be more meaningful, because learning activity that combined multimedia elements such as text, graphics, photographs, animations, video, and voice become more interactive in the learning process.(Kuswanto and Walusfa, 2017).

Based on these problems, an effort is needed so that learning activities become more interesting and enjoyable. We can make a breakthrough that could be the game. Game in this case is the game in the form of educational games. This educational game will contain materials and exercises, so it will improve student interest in learning, because the game is presented in an attractive form. This educational game also will stimulate the student in the learning process because students can learn and play (Budiman, Osmond and Saputra, 2019),

The android-based game is chosen because of today there are many smartphone users who use Android. In addition to practical, android 
smartphone also easy to use anytime and anywhere(Purnanindya and Munir, 2013).

\section{LITERATURE}

Media is anything that can deliver information from sources to recipients of information(Falahudin, 2014). Media are all forms that can be used in a process of presentation and delivery of information. The goal of media is the message can be delivered to the recipient properly.

Learning is a process of interaction of learners with educators and learning resources in a learning environment (Falahudin, 2014).Learning is a transfer of knowledge from teacher to the student, process of knowledge acquisition, mastery of skills, and also forming attitudes and characters of the students. In other words, learning is a process to help students to learn well.

Instructional media is needed in the process of learning, to reach the goal of learning. Instructional media are all things that can deliver messages from the teacher to students, which can stimulate the thoughts, feelings, and desires of students so that it will encourage the creation of learning in students (Falahudin, 2014).There are many kinds of instructional media.

The game as a multimedia interactive is one of the instructional media. The game, in this case, refers to the notion of "intellectual agility". Games can also be interpreted as a decision of the actions of his players because there are targets to be achieved, some degree of agility is a measure of the extent to which it is interesting to play the game to the fullest(Budiman, Osmond and Saputra, 2019).

Educational games are designed to be implemented in the learning process. An educational game can be an interactive and fun learning activity. Educational games is a game that is used in the learning process and in the game contains a specific lesson or educational value. (Budiman, Osmond and Saputra, 2019). From that description, it can be concluded that the learning game is one of the learning media that is expected to be a fun medium in conveying lessons so that students' understanding of material content can be better, and also expected to form students' long-term memory about the lesson.

Android is an operating system-based design of Google Linux kernel that includes an operating system, middleware, and applications (Puspitarini, 2014). Android is an Open Source software used for devices with touch screens such as smartphones and tablets. Although Android is owned by Google, but
Google does not charge for anyone who wants to use Android because Android is open source software.

Unity is a game engine based cross-platform game development consisting of gaming machines and a graphical user interface called Unity Editor (Juliani et al., 2018). Unity is an application that can be used to create games that can be used on computer, iPhone, X-Box and PlayStation (Aditya Nugraha, Son and Sukarsa, 2017). Unity is a multiplatform-based application, is applications that can publish many types of file formats, for example: exe, apk, and others. Unity need a license to be published to a particular platform, but Unity provides for free user and can be publish in the form of standalone (.exe) and the web. Unity supports 2D game development and also supports 3D gaming.

Human Senses is the interface / contact between the soul in the form of spiritual self-awareness with the environmental material. There are five senses, namely: an aid to seeing (eyes), auxiliaries to taste (tongue), auxiliaries to smell (nose), an aid to hearing (ears), and auxiliaries to feel (skin / tactile) (Legawaputri et al., 2018).

\section{RESEARCH METHOD}

The method used in the development of instructional media are using the Multimedia Development Life Cycle (MDLC) of Lutheer modified by Sutopo. The stages of MDLC is shown in Figure 1. This method consists of concept (concept), design (design), collection of material (collecting material), manufacturing (assembly), testing (testing), and distribution (distribution) (Dewi, Isnanto and Martono, 2017),

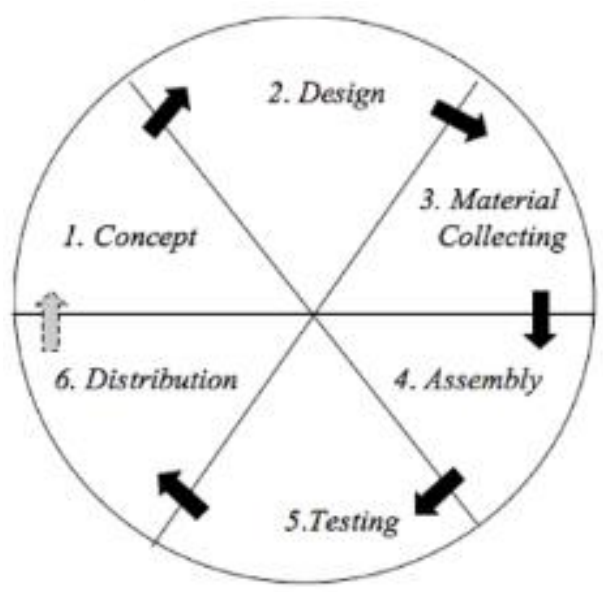

Figure 1. Multimedia Development Stages 
system. At this stage should be adjusted to the previous stages.

Making the application page display using 2dimensional images. Then the application is built using the Unity 3D game engine and to run applications using $\mathrm{C \#}$ programming language because it is in operation, Unity 3D using C\#.

\subsection{Testing}

Tests performed after completing the stage of manufacture (assembly) is completed. Application is run and see if there is a mistake or not, and adjusted to the desired expectations. This test is done by testing all in the app is running well or not or testing is better known by the name Blackbox Testing. Blackbox testing is a method of functional testing in a program (Prasetya, Sugara and Pratiwi, 2017).

\subsection{Distribution}

At this stage will be the implementation and evaluation of the application and after it was over. The application will run through a computer. Several stages of implementation and evaluation by the author names, the hardware specifications and software required to execute the application, the operation of multimedia-based applications, explain the results display, and evaluation of programs or applications.

\subsection{Design}

At this stage, every need analysis is transformed to be a design of instructional media. The purpose of this stage is to transform the result of need analysis to some diagram that can help in developing instructional media.

Documentation produced from design stage includes Flowchart and the design of the user interface. Flowchart to illustrate the flow of control. The design of the user interface is used to illustrate the display interface of instructional media.

\subsection{Material collecting}

The collection of material made in accordance with the needs that will be done. The materials collected in this stage can be in the form of instructional media material content about human senses and multimedia material such as images, photos, audio, font, and other necessities at a later stage.

\subsection{Manufacture (assembly)}

Preparation of all objects multimedia materials required in the application, then synchronize with the program code required to form an integrated

\section{RESULTS AND DISCUSSION}

The result of the design phase is designing a flowchart. The purpose of flowcharts is to document the instructional media processes and workflows. Instructional media flowchart design is divided into several menus, such as start menu, help menu, playing menu, learning menu, about menu, and the exit button. The flow of the application is described in the following flowcharts. Flowchart is shown in Figure $2-7$.

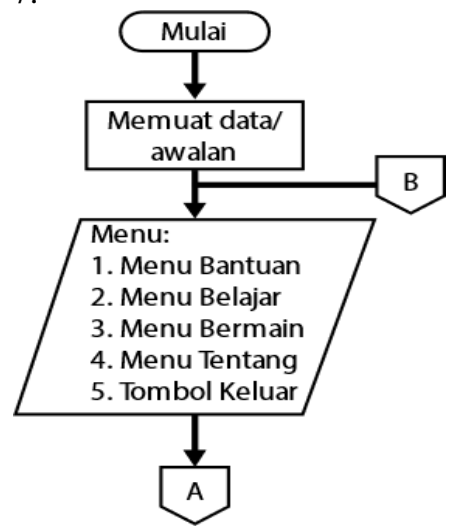

Figure 2. Flowchart Start menu. 
The main menu has the help menu, material menu, playing menu, the about the menu, and the exit button. In every menu there is a button to switch back to the previous menu, there is also a home button that redirects to the main menu. On the play menu, there is also a countdown, value, and feedback.

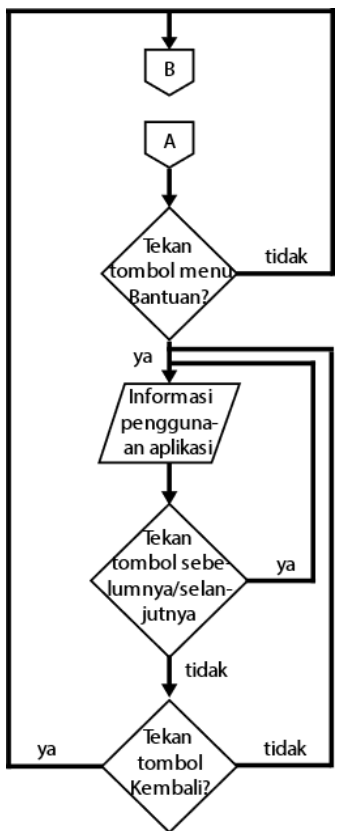

Figure 3. Flowchart of the help menu.

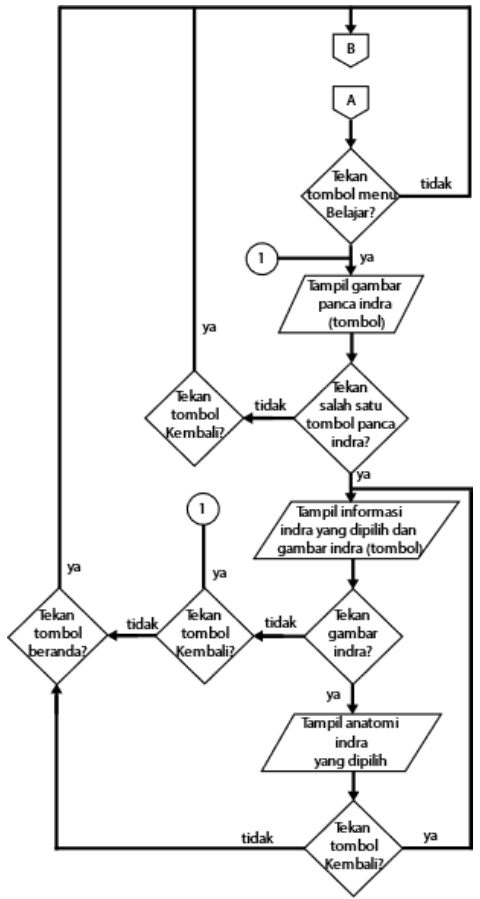

Figure 4. Flowchart of learning menu.

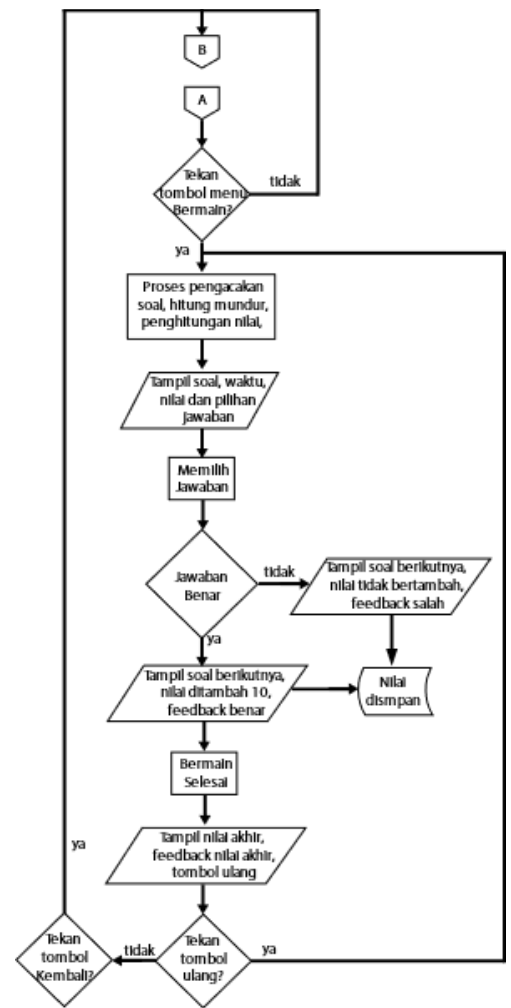

Figure 5. Flowchart of the playing menu.

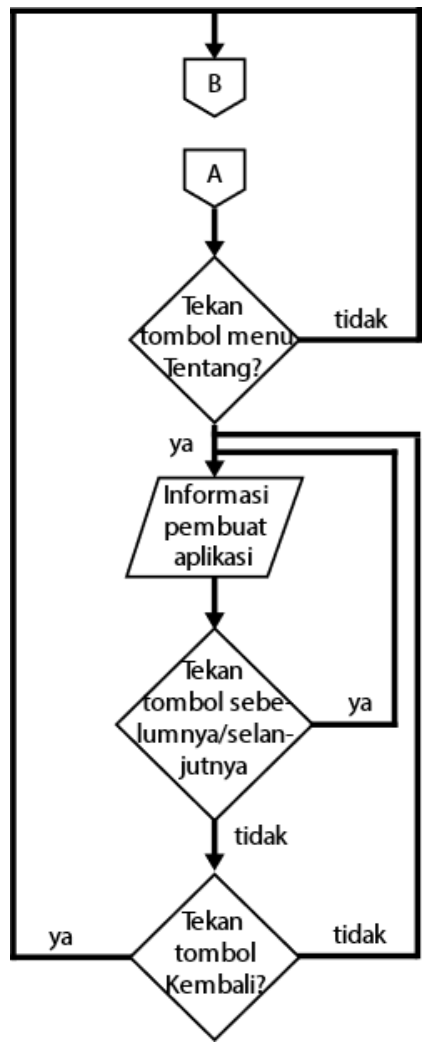

Figure 6. Flowchart of about menu. 


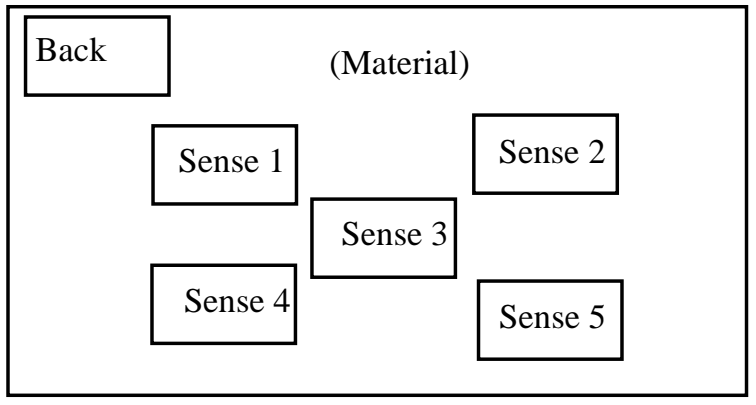

Figure 10. Design of the menu page display material.

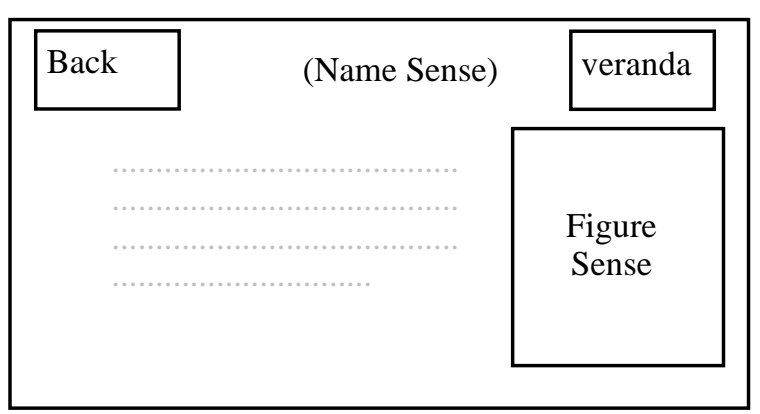

Figure 11. Design menu page display material (if you select one material).

Figure 7. Flowchart of the exit button.

After the flow diagram is created, then create a draft design of the application/user interface. There are several designs of the application. These designs was created to facilitate developers in designing application interfaces according to user needs. This design is shown in Figure 8 - 16.

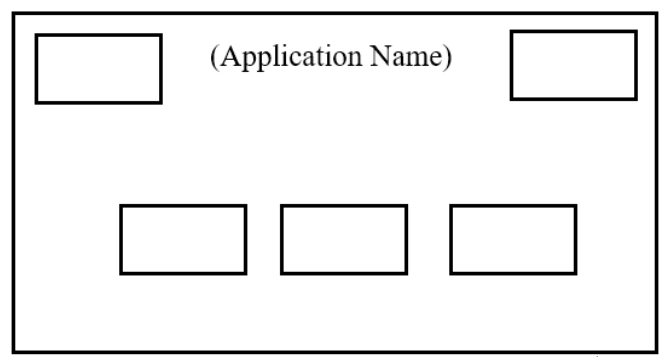

Figure 8. Design of the initial menu page views.

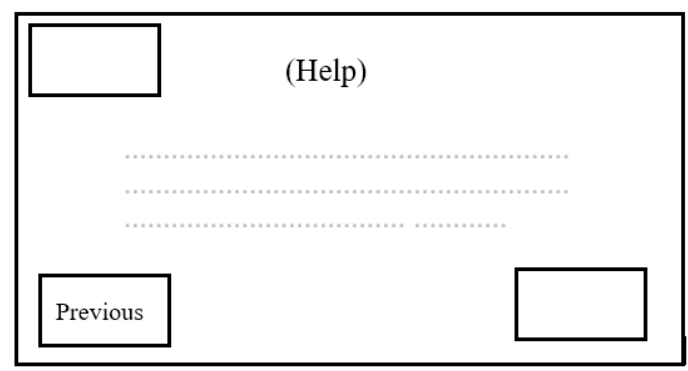

Figure 9. Design of help menu page views.

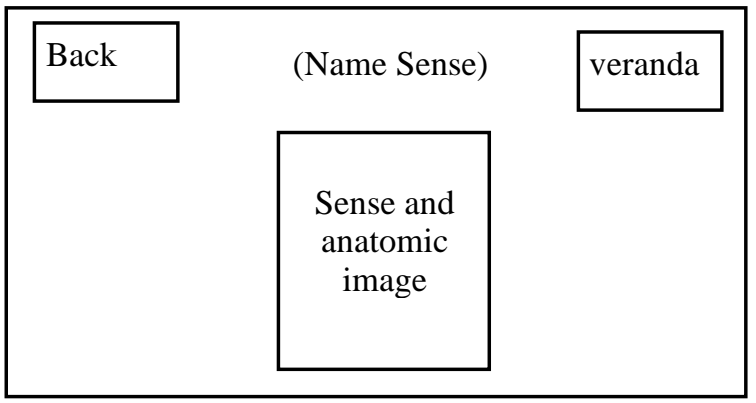

Figure 12. Design of page views anatomical sense if the image is pressed senses.

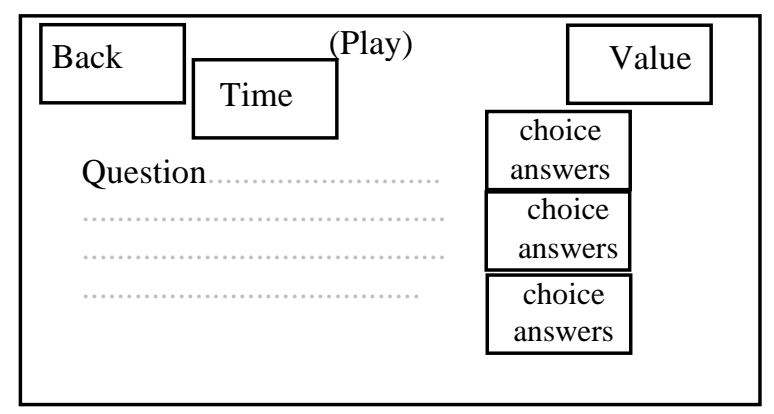

Figure 13. Design of menu page to see play. 


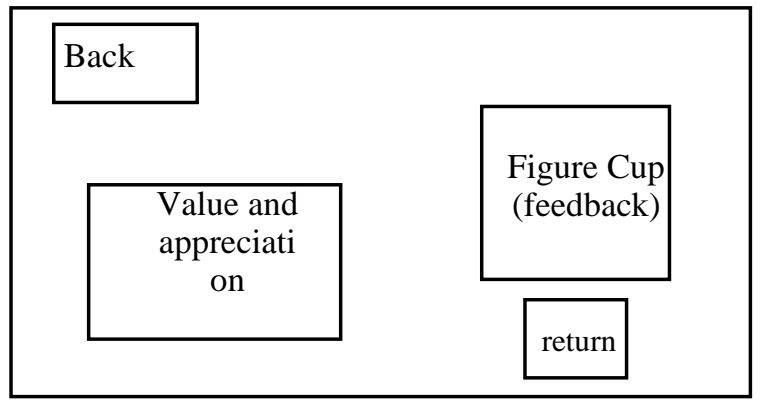

Figure 14. Design of menu page to see if it has completed the game play.

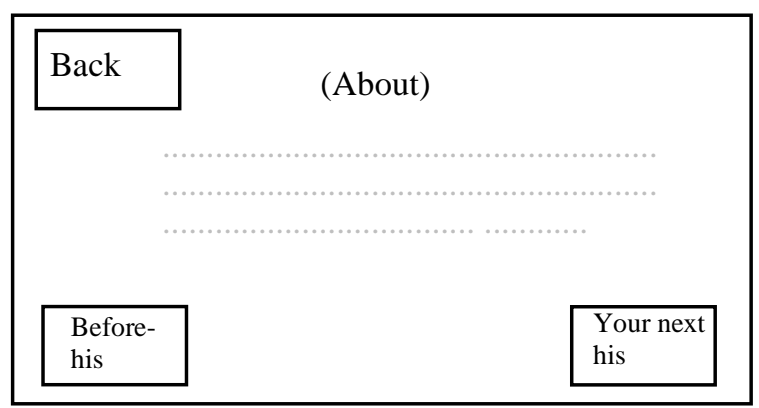

Figure 15. Design of the about menu page display.

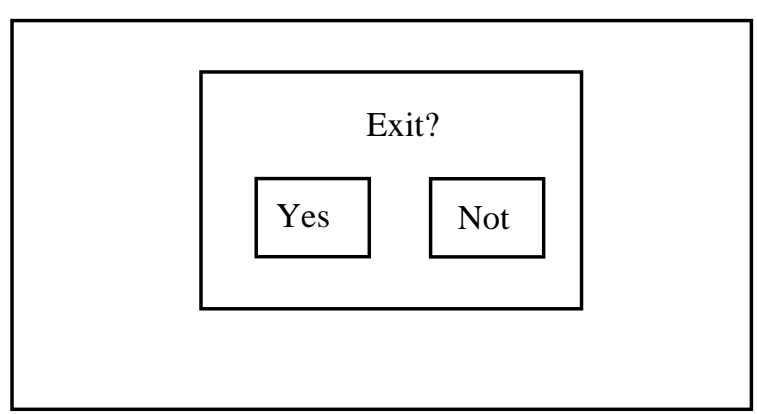

Figure 16. Design of confirmation page views for exit

Collection of material senses do as a game created discussion. The material senses obtained from various sources. The collection of images, audio sourced from the internet.

In manufacturing, the tools used to make this educational game is the Lenovo Ideapad laptop 310 and the materials used in the manufacture of this educational game is a form of software that is Microsoft Windows 10 Education, Unity 2018.3.14f1 (64-bit), Adobe Photoshop CS6, and Adobe Illustrator CC 2018. the following are the display application has been made of the equipment and materials that had been necessary.

\section{Main page}

In the application there is a main page that displays the main menu is shown in Figure 17, namely:
a. help menu,
b. learning menu,
c. playing menu,
d. about menu, and
e. Exit button.

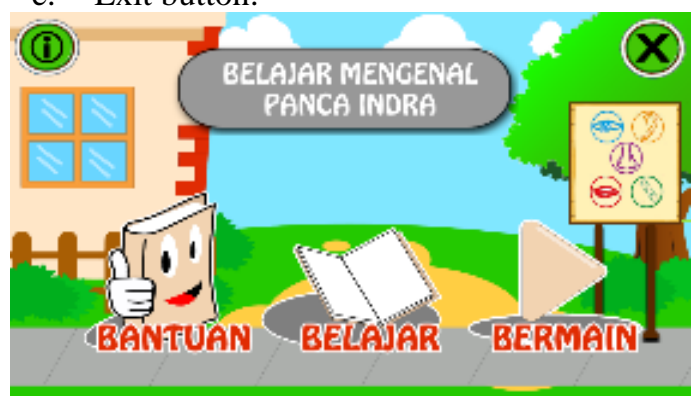

Figure 17. Display of main menu page.

a. Help menu page views

The Help menu in this application provides the functions of each button present on the application. This menu is shown in Figure 18.

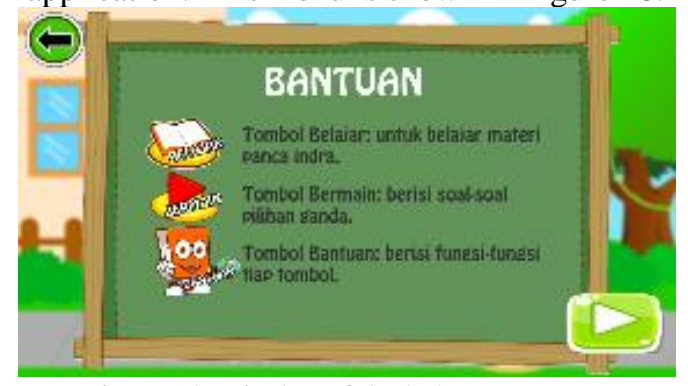

Figure 18. Display of the help menu page.

b. Learning menu page views

Contains images of the senses. If one of the images of the senses is pressed it will be presented an explanation of the five senses is pressed earlier. Furthermore, if the picture on the menu description, it will display the anatomy of the previously selected senses. This menu is shown in Figure 19-21.

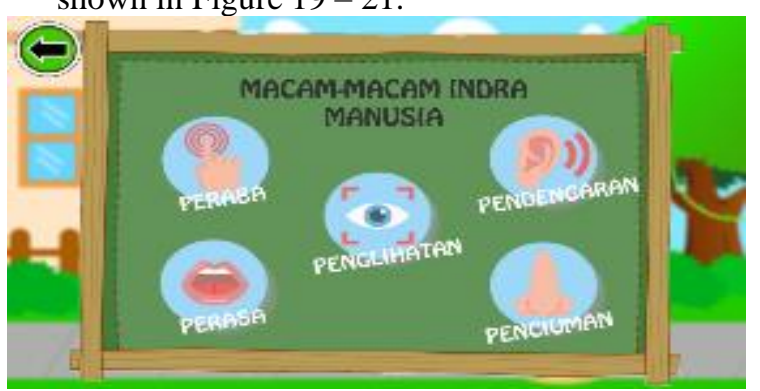

Figure 19. Display of the study menu page. 


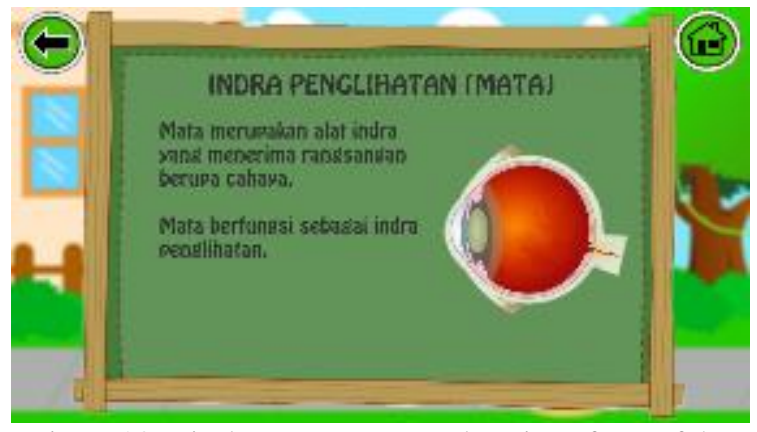

Figure 20, Display menu page explanation of one of the senses.

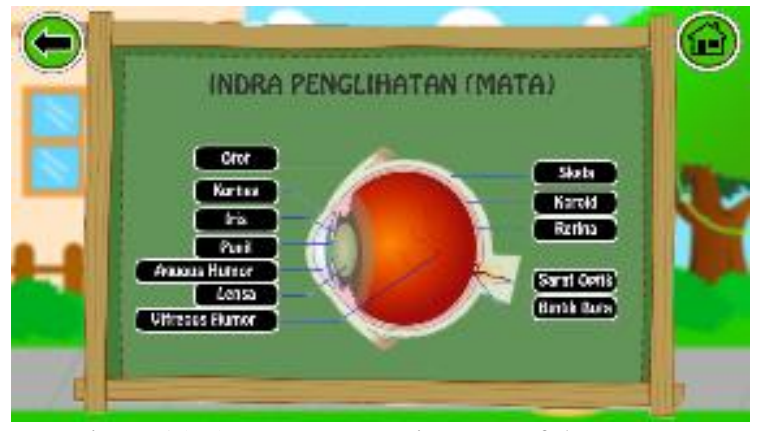

Figure 21, Anatomy page view one of the senses.

\section{c. Playing menu page of Quis}

On the menu presented 10 questions at random every start playing or repeat it. In it there is a timer that will count change matter if the time is up. Similarly, the value shown on each question. Value will increase 10 if answered correctly and got a value of zero if answered incorrectly or did not answer. After the completion of work on the problems, there will be reciprocal received by the user in the form of speech and trophies in accordance with the value obtained. Reciprocity is obtainable if users get value from 80 to 100 will get a reciprocal form of greeting "FABULOUS" and the gold trophy. If you get a score of 70 will get a reciprocal form of greeting "HOT" and a silver cup. If you get a value of 60 will get a reciprocal form of greeting "ENOUGH" and the bronze trophy. The results of this menu are shown in Figure $22-23$.

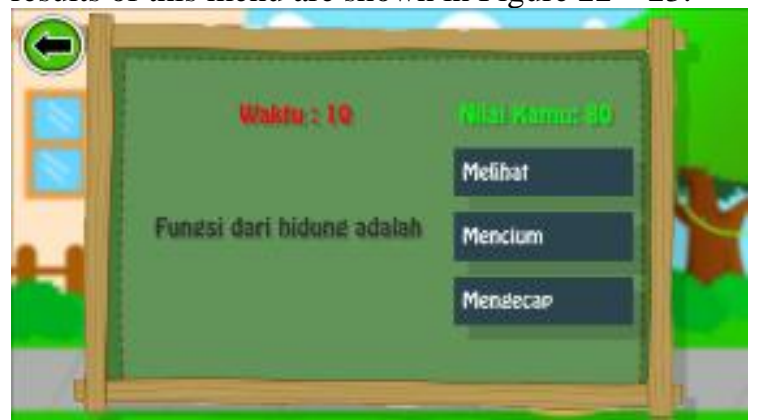

Figure 22. Display menu page of Quiz.

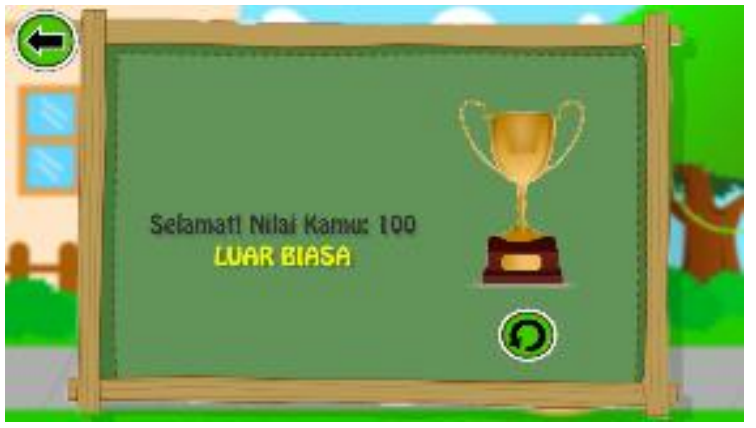

Figure 23. Display menu page play when it's finished playing.

d. Display Exit button

This exit button serves to remove the application. There is confirmation prior to exit. If the user presses the "YES" then the application will be closed and exit the application. If the user presses the "NO" it will return to the application's main menu. Display of exit button is shown in Figure 24.

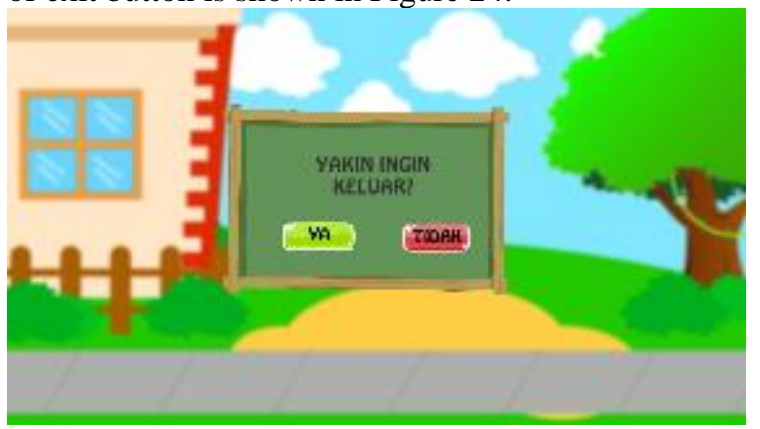

Figure 24. Page views out if a logout button press.

This application testing using the method of Blackbox testing. Testing is done by trying all the keys are functioning properly or not in accordance with expectations, the draft, and as it should.

In this test was made in the form of a table of menus and buttons on the application and shown in the Table 1.

\section{CONCLUSIONS}

\subsection{Conclusion}

Blackbox testing shows that the learning media developed can work well. This instructional media can be used on android platform. All features, menus, and buttons are functioning properly in accordance with the planning and designing of instructional media, so this instructional media is ready to be distributed.

\subsection{Suggestion}

For further development, the provision of audio supporting material is highly recommended for applications to be more interactive. 
Table 1. menus and buttons on the application

Name Testing Testing Forms $\quad$ Expected results

Test result

\begin{tabular}{|c|c|c|c|}
\hline Loading (Loading data) & Open an app & The main menu display & Well \\
\hline Tests Help menu & Pressing the Help button & $\begin{array}{l}\text { Perform all of these } \\
\text { functions and the menu } \\
\text { button on the application }\end{array}$ & Well \\
\hline Testing menu Learning & Pressing the button Learning & Featuring a variety of senses & Well \\
\hline Testing button one senses & $\begin{array}{l}\text { Pressing one of the images of } \\
\text { the senses }\end{array}$ & $\begin{array}{l}\text { Featuring an explanation of } \\
\text { the senses that have been }\end{array}$ & Well \\
\hline $\begin{array}{l}\text { Testing button sensory } \\
\text { images have been }\end{array}$ & $\begin{array}{l}\text { Pressing pictures senses } \\
\text { preselected }\end{array}$ & $\begin{array}{l}\text { Showing anatomy of the } \\
\text { senses selected }\end{array}$ & Well \\
\hline Testing Playing menu & Pressing the Play button & $\begin{array}{l}\text { Showing exercises as many } \\
\text { as } 10 \text { questions }\end{array}$ & Well \\
\hline $\begin{array}{l}\text { Testing randomization } \\
\text { algorithm matter }\end{array}$ & Tried repeatedly exercises & $\begin{array}{l}\text { Problem shown is a random } \\
\text { question that has been } \\
\text { provided on the application }\end{array}$ & Well \\
\hline Countdown time & Playing exercises & $\begin{array}{l}\text { There is the matter of time } \\
\text { that will count and changed } \\
\text { a matter if time is up }\end{array}$ & Well \\
\hline appraisal & Playing exercises & $\begin{array}{l}\text { Value will be added } 10 \\
\text { points if answered correctly } \\
\text { and do not get if the answer } \\
\text { is wrong or the processing } \\
\text { time runs out }\end{array}$ & Well \\
\hline feedback & Completing exercises & $\begin{array}{l}\text { Get a cup in accordance with } \\
\text { the values obtained (Gold, } \\
\text { Silver, Bronze, etc.) }\end{array}$ & Well \\
\hline $\begin{array}{l}\text { Testing Repeating button } \\
\text { (circular arrow direction } \\
\text { when the matter has been } \\
\text { resolved) }\end{array}$ & Pressing the button Repeating & $\begin{array}{l}\text { Repeating a matter of } \\
\text { beginning }\end{array}$ & Well \\
\hline $\begin{array}{l}\text { Testing the back button } \\
\text { (direction of the arrow to } \\
\text { the left) }\end{array}$ & Pressing the back button & Back to previous page & Well \\
\hline $\begin{array}{l}\text { Testing the Home button } \\
\text { (the houses) }\end{array}$ & Pressing the Home button & Go to the main menu & Well \\
\hline $\begin{array}{l}\text { Testing the exit button ( } \mathrm{X} \\
\text { symbol) }\end{array}$ & Pressing the exit button & $\begin{array}{l}\text { The question arises } \\
\text { confirmation of "YES" or } \\
\text { "NO" to exit }\end{array}$ & Well \\
\hline Testing the "YES" & Pressing the "YES" & Exit or close the application & Well \\
\hline Testing the "NO" & Pressing the "NO" & $\begin{array}{l}\text { Cancel out or close the } \\
\text { application and return to the } \\
\text { main menu }\end{array}$ & Well \\
\hline
\end{tabular}




\section{REFERENCES}

Aditya Nugraha, I.G., Putra, I.K.G.D. and Sukarsa, I.M. (2017). Rancang Bangun Aplikasi Augmented Reality Museum Bali Berbasis Android Studi Kasus Gedung Karangasem dan Gedung Tabanan, Lontar Komputer. Jurnal Ilmiah Teknologi Informasi, 7 (2), 93-103.

Budiman, T., Osmond, A.B. and Saputra, R.E. (2019). Aplikasi Game Edukasi Pada Android Menggunakan Qr Code Educational Game Application On Android With Qr Code. e-Proceeding of Engineering, 6 (1), 1416-1423.

Dewi, A.R., Isnanto, R.R. and Martono, K.T. (2017). Aplikasi Multimedia sebagai Media Pembelajaran Ilmu Pengetahuan Sosial Materi Budaya di Indonesia menggunakan Unity Engine untuk Sekolah Dasar, Jurnal Teknologi dan Sistem Komputer, 3 (4), 471480.

Falahudin, I. (2014). Pemanfaatan Media dalam Pembelajaran. Jurnal Lingkar Widyaiswara, 1 (4), 104-117.

Juliani, A. et al. (2018). Unity: A General Platform for Intelligent Agents. Unity Technology, 1-18.

Kuswanto, J. and Walusfa, Y. (2017). Pengembangan Modul Multimedia Interaktif Pada Mata Pelajaran Teknologi Informasi dan Komunikasi. Jurnal Pendidkan dan Teknologi Informasi, 4 (1), 104-114.

Legawaputri, M.C. et al. (2018). Implementasi Pengalaman Panca Indra pada Interior Restoran Shao Kao Surabaya. Jurnal Intra, 6 (2), 786-791.

Prasetya, E., Sugara, A. and Pratiwi, M. (2017). Pengembangan Media Pembelajaran Interaktif dengan Menggunakan Metode Multimedia Development Life Cycle. Jurnal Online Informatika, 2 (2), 121-126.

Purnanindya, R. and Munir, M. (2013). Pengembangan Game Edukasi Ular Tangga Sebagai Media Pembeajaran TIK untuk Siswa Kelas 3 SD Negeri Pujokusuman 2 Yogyakarta. Jurnal Elektronik Pendidikan Teknik Informatika, 2 (1), 1-4.

Puspitarini, D.W.P.A.P.N.E.W. (2014). Game Edukasi Berbasis Android Sebagai Media Pembelajaran Untuk Anak Usia Dini. Jurnal Teknologi Informasi dan Komunikasi, 5 (1), 47-55. 